\title{
Rancang Bangun Sistem Informasi Proses Tugas Akhir
}

(Studi Kasus: Program Studi Teknik Informatika Universitas Sam Ratulangi)

Frisilia Meiny Tuturoong, Rizal Sengkey, Xaverius Najoan

Teknik Informatika Universitas Sam Ratulangi Manado, Indonesia.

frisiliameinytuturoong@gmail.com, rizalsengkey@gmail.com, xnajoan@unsrat.ac.id

\begin{abstract}
Abstrak - Tugas Akhir atau Skripsi adalah istilah yang digunakan di Indonesia untuk mengilustrasikan suatu karya tulis ilmiah berupa paparan tulisan hasil penelitian Strata satu (S1) yang membahas suatu permasalahan/fenomena dalam bidang ilmu tertentu dengan menggunakan kaidah-kaidah yang berlaku. Dalam penulisan tugas akhir, mahasiswa dibimbing oleh satu atau dua orang pembimbing yang berstatus dosen dalam perguruan tinggi tempat mahasiswa tersebut kuliah. Adapun beberapa proses dalam penyusunan tugas akhir mulai dari pengajuan proposal, penelitian, seminar hasil, hingga melakukan revisi sesuai dengan masukan dosen. Proses-proses tersebut perlu didukung oleh implementasi teknologi informasi yaitu dengan penggunaan Web sebagai media pelaksana. Metodologi yang digunakan adalah Rational Unified Process (RUP). Kelebihan dari sistem ini yaitu penggunaannya sangat mudah dimengerti dan mempermudah proses penyusunan tugas akhir.
\end{abstract}

Kata kunci - Web, Tugas Akhir/Skripsi, Rational Unified Process

\section{PENDAHULUAN}

Implementasi teknologi informasi memiliki peran yang besar terlebih dengan adanya sistem yang mampu mempermudah proses-proses dalam penyusunan tugas akhir/skripsi. Salah satunya yaitu dengan Web. Penggunaan Web sebagai media pelaksana proses penyusunan tugas akhir/skripsi diseluruh Universitas di Indonesia pada umumnya dan di Fakultas Teknik Universitas Sam Ratulangi Manado pada khususnya dianggap sangat diperlukan karena dapat memberikan dukungan penuh pada bidang akademik ini. Adapun kesempatan untuk membangun suatu perangkat lunak yang dapat memudahkan mahasiswa dalam proses penyusunan tugas akhir dengan mengakses Website yaitu dengan merancang dan membangun suatu sistem informasi.

\section{LANDASAN TEORI}

\section{A. Sistem Informasi}

Sistem Informasi (SI) merupakan sebuah proses menjalankan fungsi mengumpulkan data (input), memproses, menyimpan, menganalisis, dan menyebarkan informasi (output) untuk suatu kepentingan tertentu. Sederhananya, sebuah sistem informasi akan menerima input berupa data, data ini akan disimpan (storage) dan kemudian akan diproses untuk menghasilkan sebuah output.[1]

\section{B. Tugas Akhir}

Tugas Akhir adalah karya tulis mahasiswa yang menunjukkan puncak proses berpikir ilmiah, kreatif, integratif, dan sesuai dengan disiplin ilmu yang disusun untuk memenuhi persyaratan penyelesaian studi dalam program Diploma dan Strata satu (S1) di lingkungan UNP. Dalam penulisan tugas akhir, Mahasiswa dibimbing oleh satu atau dua orang pembimbing yang berstatus dosen pada perguruan tinggi tempat Mahasiswa tersebut kuliah.

Proses penyusunan tugas akhir adalah sebagai berikut:

1. Pengajuan judul tugas akhir.

2. Pengajuan proposal tugas akhir.

3. Seminar proposal tugas akhir.

4. Penelitian tugas akhir.

5. Seminar hasil tugas akhir.

6. Mahasiswa yang hasil seminarnya diterima, melakukan revisi sesuai dengan masukan Dosen.

7. Setelah penulisan dianggap siap dan selesai, Mahasiswa mempresentasikan hasil tugas akhir tersebut pada Dosen penguji (sidang tugas akhir).

8. Mahasiswa yang hasil ujian tugas akhir diterima dengan revisi, melakukan revisi sesuai dengan masukan Dosen penguji.

\section{Website}

Website atau situs dapat diartikan sebagai kumpulan halaman-halaman yang digunakan untuk menampilkan informasi teks, gambar diam atau gerak, animasi, suara, dan atau gabungan dari semuanya, baik yang bersifat statis maupun dinamis, yang membentuk satu rangkaian bangunan yang saling terkait, yang masing-masing dihubungkan dengan jaringan-jaringan halaman.[2] 
III. METODOLOGI PENELITIAN

Metodologi penelitian menggunakan pendekatan Rational Unified Process (RUP).

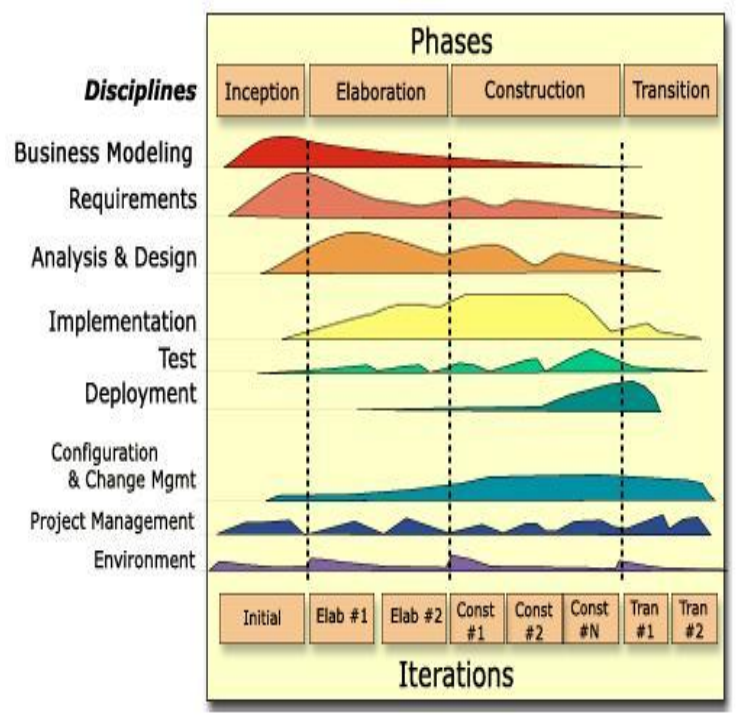

Gambar 1. Arsitektur Rational Unified Process

\section{A. Inception}

Pada tahap ini, kita akan menentukan ruang lingkup dan membuat business case.

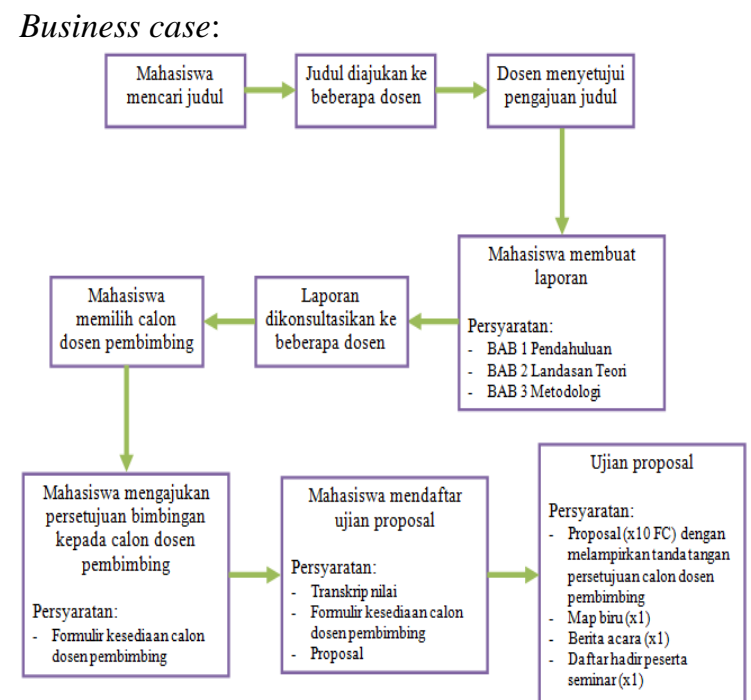

Gambar 2. Proses Manual

Ruang lingkup:

1. Mempelajari dasar pengolahan data dalam suatu Website.

2. Menganalisis masalah dan kesempatan yang dapat terjadi dalam proses mendapatkan informasi dari Website ini.

3. Mengumpulkan informasi yang berkaitan dengan pembuatan Website khususnya sistem informasi proses penyusunan tugas akhir, kemudian diproses menjadi sebuah data yang berguna untuk pengembangan sistem.
4. Merancang antarmuka dan algoritma untuk sistem yang akan dibangun.

5. Membuat fitur-fitur untuk Admin, Dosen, dan Mahasiswa.

6. Mempelajari pemrograman menggunakan PHPMyAdmin dengan menggunakan bantuan $X A M P P$ sebagai Web Server sekaligus pengolah database.

\section{B. Elaboration}

Pada tahap ini, kita akan menganalisis persyaratan dan menetapkan baseline.

Persyaratan pengembangan dengan mengembangkan fitur-fitur sebagai berikut:

\section{Form Admin}

a. Fitur Daftar mahasiswa, fitur ini berfungsi untuk mengolah data Mahasiswa.

b. Fitur Daftar dosen, fitur ini berfungsi untuk mengolah data Dosen.

c. Fitur Operasi, fitur ini berfungsi untuk mengolah data proses pengajuan dan penyusunan tugas akhir.

d. Fitur Search, fitur ini berfungsi untuk mencari data Mahasiswa dengan memasukkan nama atau NIM Mahasiswa tersebut.

e. Fitur Keluar, fitur ini berfungsi untuk keluar dari sistem.

2. Form Dosen

a. Fitur Mahasiswa, fitur ini berfungsi untuk melihat daftar Mahasiswa yang dibimbing.

b. Fitur Konsultasi, fitur ini berfungsi untuk melihat daftar konsultasi yang dikirimkan oleh Mahasiswa.

c. Fitur Persetujuan, fitur ini berfungsi untuk memberitahukan apakah judul dan bimbingan yang diajukan disetujui atau tidak.

3. Form Mahasiswa

a. Fitur Judul, fitur ini berfungsi untuk pengajuan judul tugas akhir beserta calon dosen pembimbing.

b. Fitur Proposal, fitur ini berfungsi untuk bimbingan dan konsultasi proposal dalam bentuk softcopy file.

c. Fitur Konsultasi, fitur ini berfungsi untuk melihat percakapan dengan Dosen pembimbing.

d. Fitur Informasi, fitur ini berfungsi untuk melihat status proposal yang diajukan disetujui atau tidak oleh Dosen. 
Baseline arsitektur sistem dengan menggunakan

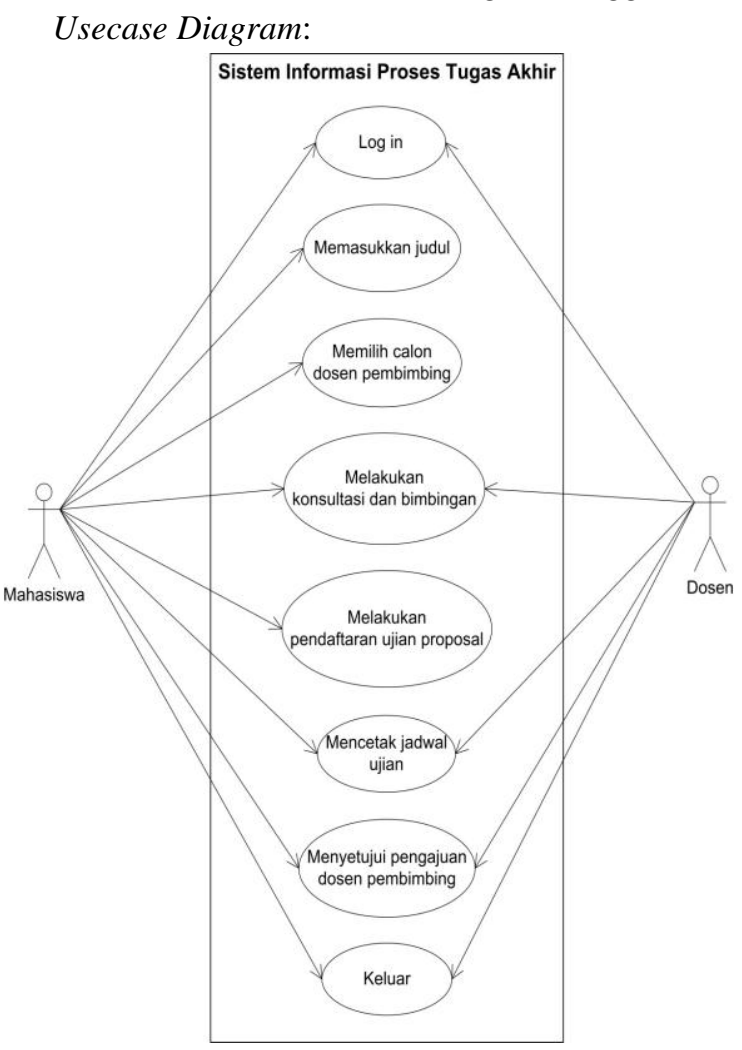

Gambar 3. Usecase Diagram Mahasiswa dan Dosen

\section{Construction}

Pada tahap ini, kita akan mengimplementasikan perangkat lunak pada kode program sebagai berikut:

1. Menggunakan aplikasi PHPMyAdmin untuk melakukan pemrograman.

2. Menggunakan aplikasi XAMPP sebagai Web Server untuk mengolah database.

3. Menggunakan aplikasi Adobe Photoshop CS4 untuk perancangan interface.

4. Menggunakan aplikasi Mozilla firefox, Google chrome, dan Internet explorer untuk menjalankan sistem.

\section{HASIL DAN PEMBAHASAN \\ D. Transition}

Pada tahap ini, kita akan membuat apa yang sudah dimodelkan menjadi suatu produk jadi dan melakukan testing.

Dibawah ini merupakan tampilan halaman utama ketika pengguna membuka sistem. Sistem menyediakan menu utama berupa menu Home, Kampus, Tentang, Lokasi, dan Log in.

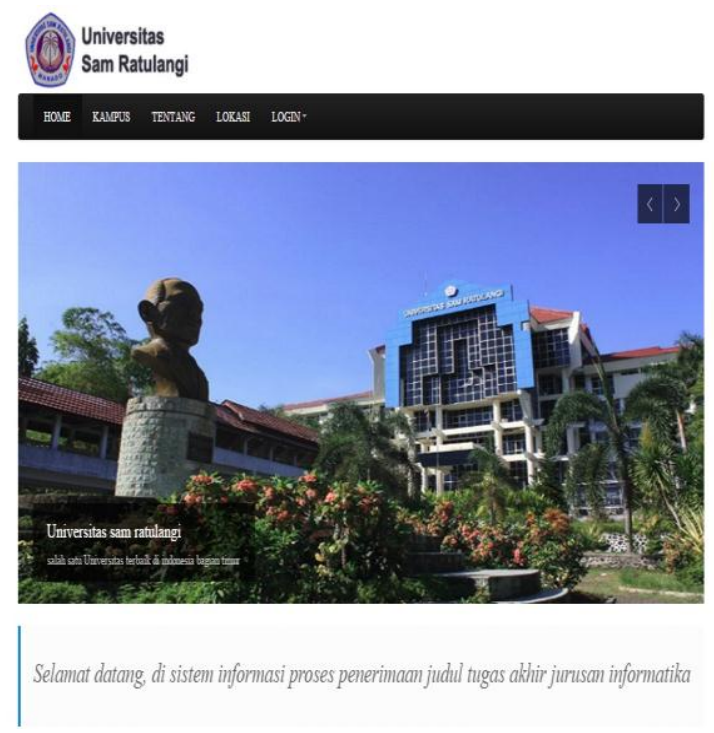

Gambar 4. Halaman Utama Sistem

Dibawah ini merupakan tampilan halaman ketika pengguna memilih menu $\log$ in. $\log$ in menyediakan hak akses untuk Admin, Dosen, dan Mahasiswa dengan memasukkan username dan password.

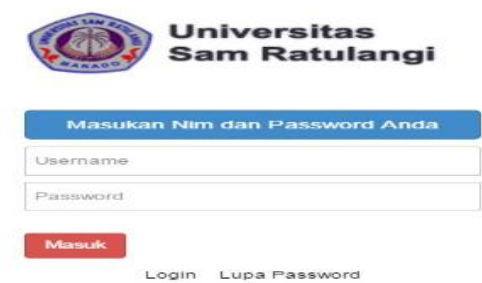

Gambar 5. Halaman Log in

Dibawah ini merupakan tampilan halaman ketika pengguna berhasil masuk ke menu Admin. Admin dapat menambah, mengedit, dan menghapus data Mahasiswa serta Dosen.

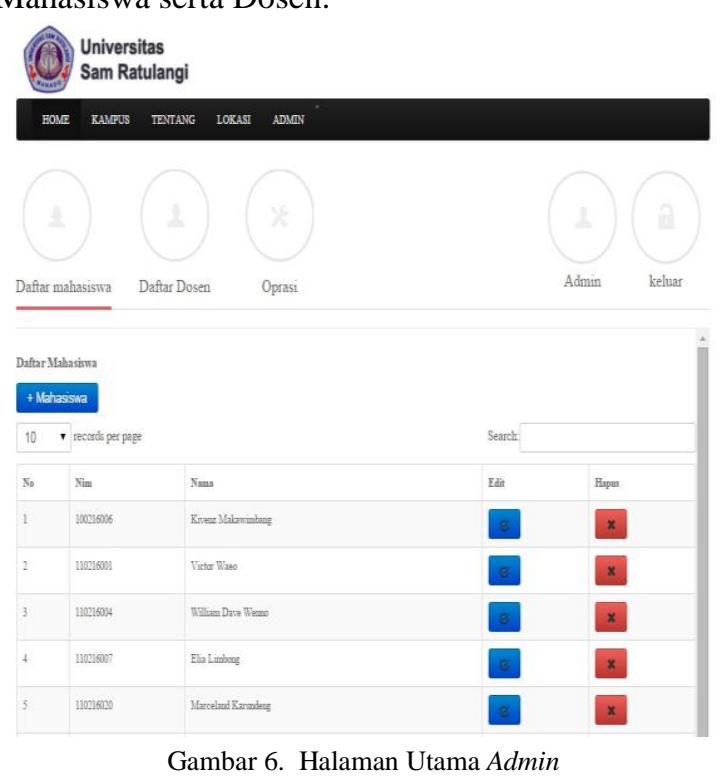


Dibawah ini merupakan tampilan halaman ketika Admin memilih fitur Operasi. Halaman ini menyediakan fitur-fitur operasional yaitu, fitur Lihat Pengajuan Judul, Lihat Judul Yang Telah Disetujui, Daftar Proposal Mahasiswa, Daftar Pengajuan Proposal, Daftar Skripsi Mahasiswa, Atur Bimbingan, Atur Log in Mahasiswa dan Dosen, serta fitur Atur Jadwal Ujian Proposal dan Skripsi.

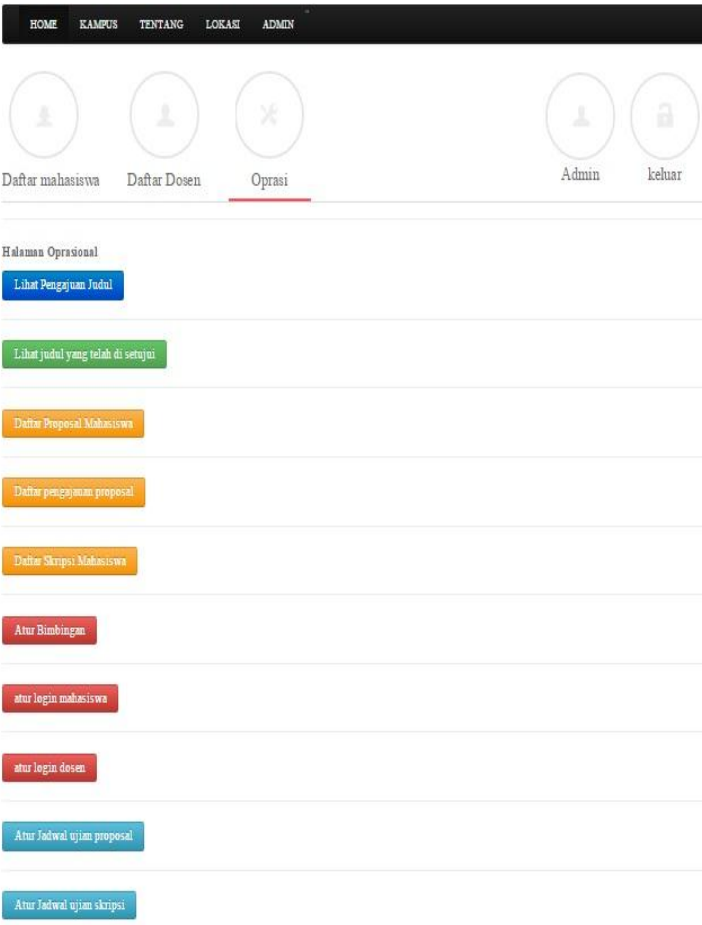

Gambar 7. Halaman Operasi Admin

Dibawah ini merupakan tampilan halaman ketika pengguna berhasil masuk ke menu Mahasiswa. Mahasiswa memulai dengan memasukkan judul tugas akhir dan memilih calon dosen pembimbing.
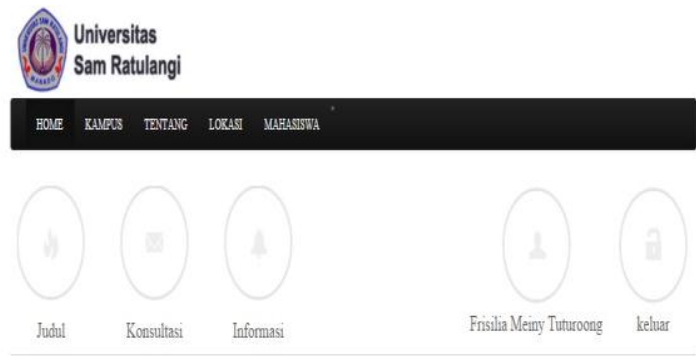

$$
\begin{aligned}
& \text { Hahman Pengjian Judul Iugsa Altiri } \\
& \text { Ajtann Ididal } \\
& \text { Rancang Bangun Sstem Iroma } \\
& \text { Ajomententivinging } 1 \\
& \text { Riza Sergke, ST, IIT ， } \\
& \text { Ajizan Peatinting? } \\
& \text { Xarenus B . N Majacan, ST, I , }
\end{aligned}
$$

Gambar 8. Halaman Utama Mahasiswa
Dibawah ini merupakan tampilan halaman ketika Admin melakukan operasi Lihat Pengajuan Judul. Admin akan menyetujui atau menolak pengajuan judul dan calon dosen pembimbing oleh Mahasiswa.

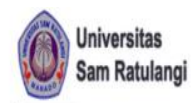

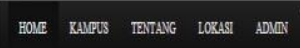

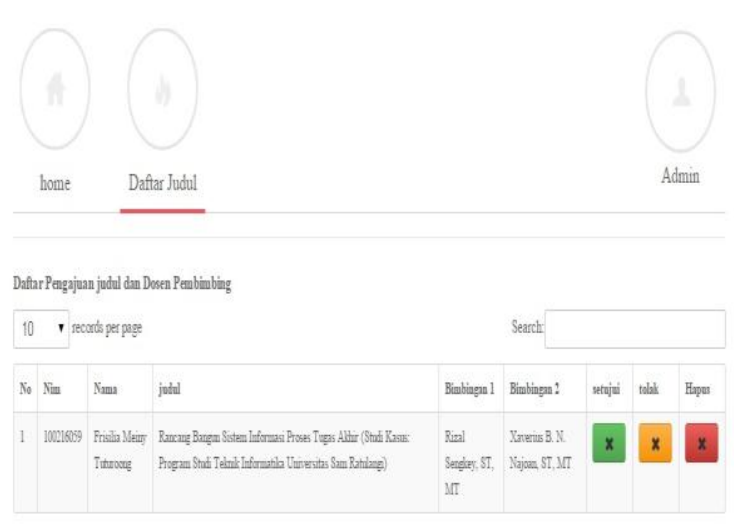

Gambar 9. Halaman Lihat Pengajuan Judul

Dibawah ini merupakan tampilan halaman ketika pengguna berhasil masuk ke menu Dosen. Dosen akan melihat daftar Mahasiswa bimbingan.

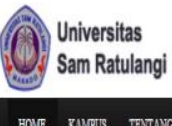

BONE RAMUS TRTANG LORAS DOSEN

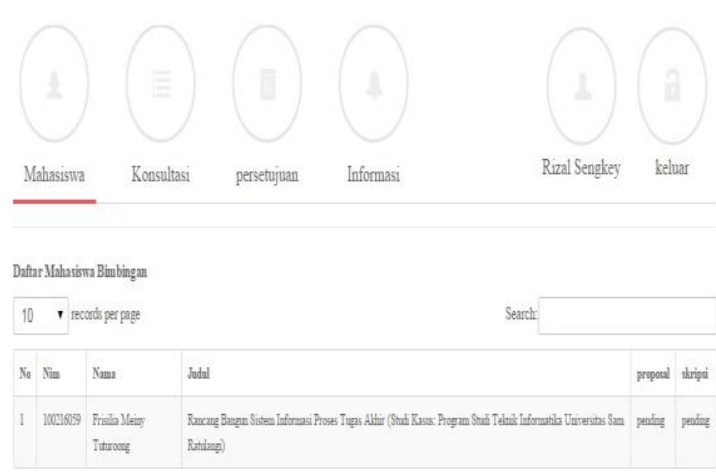

Gambar 10. Halaman Utama Dosen

Dibawah ini merupakan tampilan halaman ketika Mahasiswa memilih fitur Proposal. Mahasiswa akan memulai konsultasi dengan Dosen. Mahasiswa akan memilih nama Dosen, lalu memasukkan dokumen yang akan dikonsultasikan dalam format PDF, dan memasukkan keterangan dalam bentuk pernyataan ataupun pertanyaan untuk kemudian dikirimkan kepada Dosen yang dimaksud. 


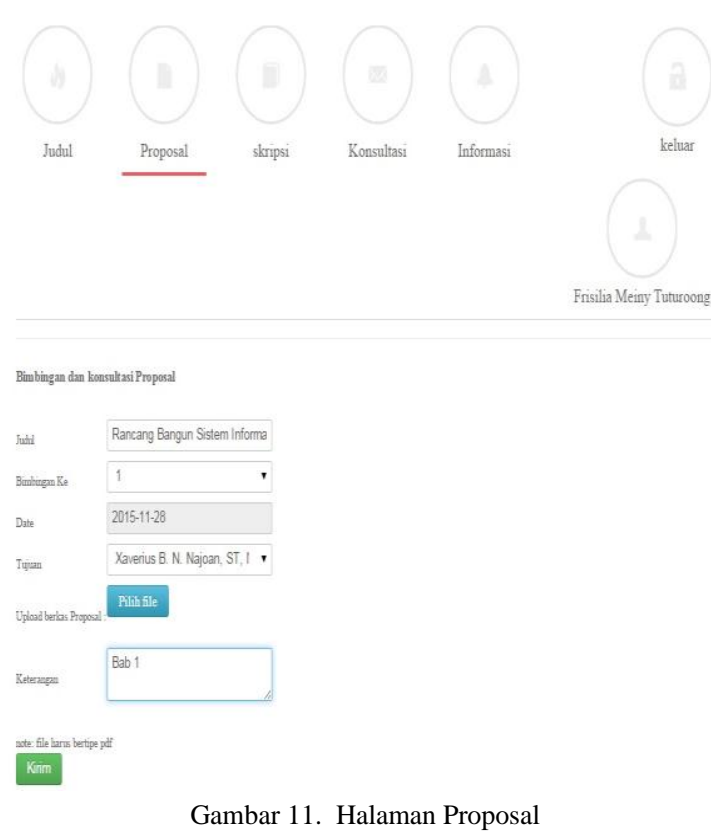

Dibawah ini merupakan tampilan halaman ketika Dosen memilih fitur Konsultasi Proposal. Dosen dapat melihat, mengomentari, dan mengunduh file yang dikirimkan Mahasiswa.

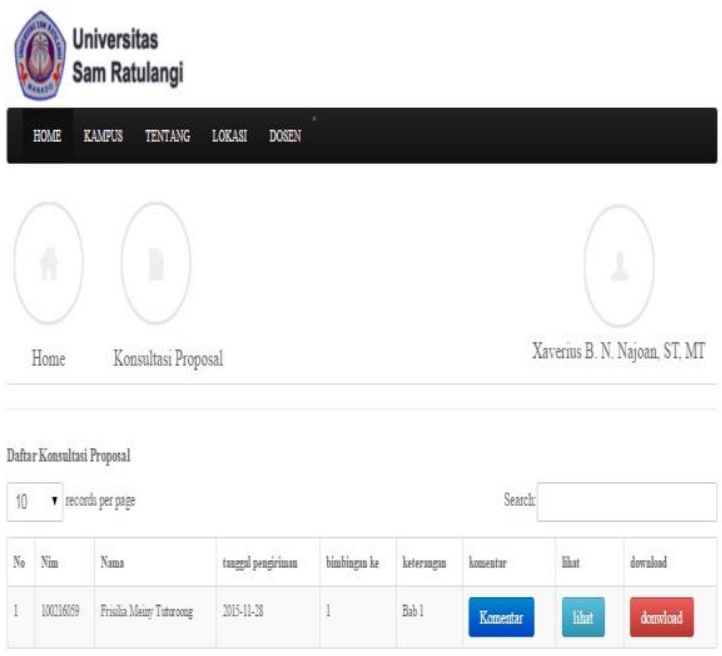

Gambar 12. Halaman Konsultasi Proposal

Dibawah ini merupakan tampilan halaman ketika Mahasiswa memilih fitur Daftar Ujian Proposal. Mahasiswa akan memasukkan judul tugas akhir dan memilih calon Dosen pembimbing yang sesuai.

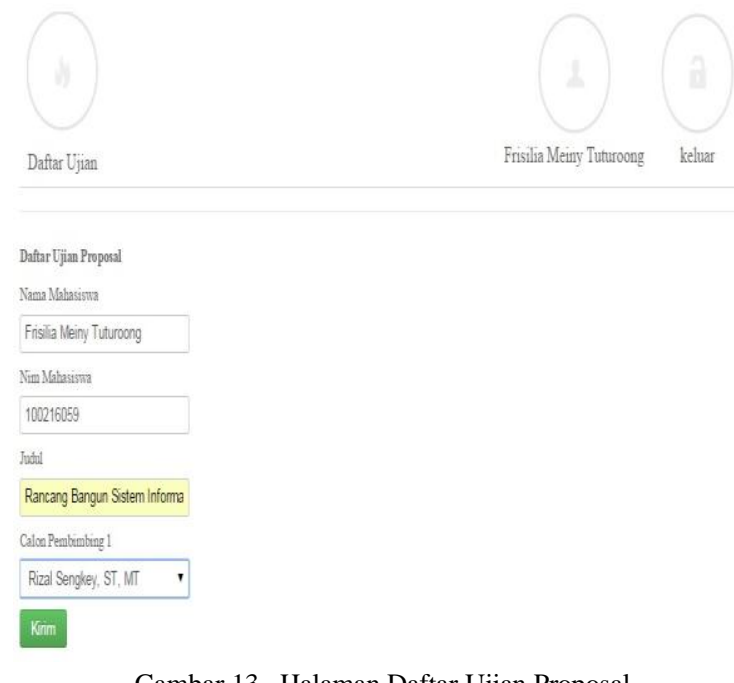

Gambar 13. Halaman Daftar Ujian Proposal

Dibawah ini merupakan tampilan halaman ketika Admin memilih fitur Atur Jadwal Ujian Proposal. Admin akan memasukkan nama Mahasiswa dan mengatur tanggal/waktu serta keterangan untuk ujian.

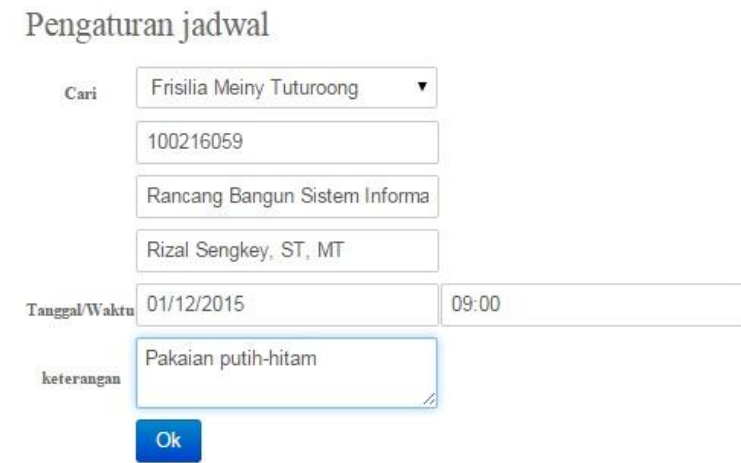

Gambar 14. Halaman Atur Jadwal Ujian Proposal

Dibawah ini merupakan tampilan halaman ketika Mahasiswa memilih fitur Informasi. Mahasiswa dapat melihat status konsultasi dan jadwal ujian hingga mencetak jadwal ujian proposal.

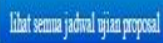

Itim: 10020605:

Nean: Fasiallemy Throwg

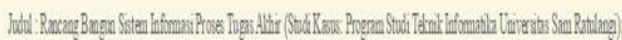

Peediating Ral Sader, STIMI

Thegal 2015.1201.

lam 000100

Retrengen: Paimnothititan

Gambar 15. Halaman Informasi 


\section{PENUTUP}

\section{A. Kesimpulan}

Kesimpulan yang didapat:

Berdasarkan hasil penelitian telah dibangun suatu sistem informasi proses tugas akhir yang berbasis Web melalui beberapa proses antara lain penentuan business case, pembuatan arsitektur sistem, pengkodean, dan pengujian sistem. Sistem ini dapat digunakan oleh Dosen dan Mahasiswa untuk proses tugas akhir sehingga dapat memudahkan proses konsultasi dan bimbingan tugas akhir.

\section{B. Saran}

Saran pengembangan sistem kedepannya:

a) Menambah menu untuk administrasi dan pengurusan surat keputusan dalam proses tugas akhir.

b) Sistem informasi ini bisa lebih dikembangkan dengan menambah studi kasus pada program studi lainnya.

\section{DAFTAR PUSTAKA}

[1] Bonnie Soeherman, Steven Ariyanto, Maria Vanessa Yuliani. 2010. Membangun Sistem Informasi UMKM Jasa Dengan MS ACCESS. Jakarta: Elex Media Komputindo.

[2] Ceria Marcelina. 2012. Analisa Sistem Multimedia Audio Gallery Ilearning Community And Services (MAGICS) Dalam Mendukung Pembelajaran ILearning Di Perguruan Tinggi Raharja. Tanggerang.

[3] Japerson Hutahean. 2014. Konsep Sistem Informasi Yogyakarta: Deepublish.

[4] Priyanto Hidayatullah, Jauhari Khairul Kawistara. 2014. Pemrograman Web. Bandung. Informatika Bandung.

[5] Roger S Pressman, Ph.D. 2012. Rekayasa Perangkat Lunak Pendekatan Praktisi Edisi 7. Yogyakarta. Andi.

[6] Rosa, A.S, Shalahudin, M. 2011. Modul Pembelajaran Rekayasa Perangkat Lunak. Jakarta. Modula.

[7] Sri Susanti. 2012. Peningkatan Keterampilan Menulis Eksposisi Siswa Kelas X Man BINTAN Kepulauan RIAU Melalui Metode Klasifikasi. Padang. [Accesed 13 Agustus 2015].

[8] Tim Penyusun. 2010. Buku Panduan Program Pendidikan Tinggi Teknik Sipil Arsitektur Mesin Elektro 1964-2010 Fakultas Teknik UNSRAT Manado.Manado.

[9] Wildan Faizanni. 2010. Pengertian DBMS (Database Management System).

http://wildanfaizanni.wordpress.com/2010/04/03/pengertia n-dbms-database-management-system/ [Accesed 13 Agustus 2015].

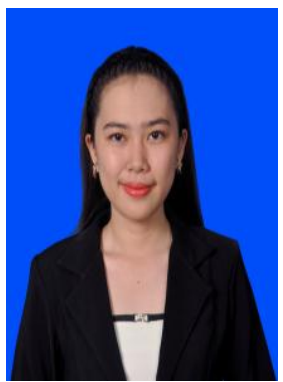

Sekilas dari penulis dengan nama lengkap Frisilia Meiny Tuturoong, lahir di kota Bitung, Provinsi Sulawesi Utara. Anak ke-3 dari 3 bersaudara. Dengan pendidikan Taman Kanak-kanak GMIM Nafiri Bitung. Kemudian melanjutkan ke Sekolah Dasar SD Katolik 2 Don Bosco Bitung. Kemudian melanjutkan ke Sekolah Menengah Pertama SMP Katolik Don Bosco Bitung. Kemudian melanjutkan ke Sekolah Menengah Atas SMA Negeri 2 Bitung. Setelah lulus tahun 2010 melanjutkan ke Perguruan Tinggi di Universitas Sam Ratulangi Manado dengan mengambil jurusan Teknik Infortmatika. Pada tahun 2015 bulan Maret, penulis membuat skripsi demi memenuhi syarat Sarjana (S1) dengan penelitian berjudul Rancang Bangun Sistem Informasi Proses Tugas Akhir (Studi Kasus: Program Studi Teknik Informatika Universitas Sam Ratulangi) yang dibimbing oleh dua dosen pembimbing yaitu Rizal Sengkey, ST., MT dan Xaverius Najoan, ST., MT sehingga pada tanggal 2 Februari 2016 penulis resmi lulus di Teknik Informatika Universitas Sam Ratulangi Manado dan menyandang gelar sebagai Sarjana Komputer dengan predikat Sangat Memuaskan. 